\title{
Ocular biometry and central corneal thickness in children: a hospital-based study
}

\section{Biometria ocular e espessura corneana central em crianças: um estudo de base hospitalar}

\author{
Adem Gul ${ }^{1}$, Cagatay Caglar ${ }^{2}$, Adnan Cinal ${ }^{3}$, Tekin Yasar ${ }^{4}$, Adil Kilic ${ }^{5}$
}

\begin{abstract}
Purpose: To investigate the distribution of axial length, anterior chamber depth, lens thickness, vitreous chamber depth, and central corneal thickness in children at different age groups.

Methods: We studied 364 eyes in 182 children with ages between 1 and 12 years. Axial length, anterior chamber depth, lens thickness, and vitreous chamber depth were measured by ultrasound biometry. Central corneal thickness was measured by ultrasound pachymetry in all children.

Results: The mean age was $6.54 \pm 3.42$ years. The axial length was $20.95 \mathrm{~mm}$ in $1-2$ years old and $22.95 \mathrm{~mm}$ in 11-12 years old. The central corneal thickness was $556 \mu \mathrm{m}$ in 1-2 years old and $555 \mu \mathrm{m}$ in 11-12 years old. The mean anterior chamber depth and vitreous chamber depth increased with age $(3.06 \mathrm{~mm}$ to $3.44 \mathrm{~mm}$ in anterior chamber depth, $13.75 \mathrm{~mm}$ to $15.99 \mathrm{~mm}$ in vitreous chamber depth), and the lens thickness decreased as age increased (3.67-3.51 mm).

Conclusion: The axial length increased with age and reached adult levels by the age of 9-10 years. The lens thickness gradually decreased until 12 years. The central corneal thickness measurements did not yield a linear algorithm.
\end{abstract}

Keywords: Biometry; Cornea/anatomy \& histology; Axial length eye; Child

\section{RESUMO}

Objetivo: Investigar a distribuição do comprimento axial, profundidade da câmara anterior, espessura do cristalino, profundidade da câmara vítrea e espessura corneal central em crianças em diferentes faixas etárias.

Métodos: Foram estudados 364 olhos de 182 crianças entre 1 e 12 anos de idade. 0 comprimento axial, a profundidade da câmara anterior, a espessura do cristalino e a profundidade da câmara vítrea foram medidos por biometria ultrassônica. A espessura corneal central foi medida por paquimetria ultrassônica em todas as crianças.

Resultados: A idade média foi de 6,54 $\pm 3,42$ anos. O comprimento axial foi 20,95 mm no grupo de 1-2 anos de idade e 22,95 mm no grupo de 11-12 anos de idade. A espessura corneal central foi $556 \mu$ m no grupo de 1 -2 anos de idade e $555 \mu \mathrm{m}$ no grupo de 11-12 anos de idade. A profundidade da câmara anterior média e profundidade da câmara vítrea aumentou com aidade $(3,06 \mathrm{~mm}$ a 3,44 $\mathrm{mm}$ de profundidade da câmara anterior, 13,75 mm a 15,99 mm de profundidade da câmara vítrea) e da espessura do cristalino diminuiu com o aumento da idade $(3,67 \mathrm{~mm}$ a 3,51 $\mathrm{mm}$ ).

Conclusões: Em nosso estudo, os valores do comprimento axial aumentou com a idade e atingiu os níveis adultos aos 9-10 anos de idade. A espessura do cristalino diminuiu gradualmente até os 12 anos de idade. As medições de espessura corneal central não seguiu um algoritmo linear.

Descritores: Biometria; Córnea/anatomia \& histologia; Comprimento axial do olho; Criança

\section{INTRODUCTION}

Ocular biometry, the refractive status of developing human eyes and how they change with age, is essential for understanding the ocular growth and development of other ocular pathologies.

Many published studies have examined ocular biometry in older populations and have provided significant data. However, there are few population-based age norms for ocular biometry in children due to the technical difficulties in measuring biometric parameters, particularly in small children ${ }^{(1)}$. When we searched for pediatric ocular biometric studies in the ophthalmology literature, we noted some restrictions in the design of previous studies, particularly those with school-age children. There was a paucity of data regarding biometry and central corneal thickness in preschool children. We decided to search for both preschool and school age children to investigate the normal distribution of axial length and central corneal thickness among children in different age groups.

Ocular biometric status varies in different ethnicities. Therefore, data from different areas and ethnicities should be studied. In this article, we present data for ocular biometry and central corneal thickness in a pediatric population. This data contributes to the literature by studying the Caucasian population in the eastern region of Turkey.

\section{METHODS}

This study was carried out in Yuzuncu Yil University, Faculty of Medicine, Ophthalmology Department. It was approved by the Human Ethics Committee at Yuzuncu Yil University. The research adhered to the tenets of the Declaration of Helsinki.

The study was performed prospectively. Subjects were children between the ages of 1 and 12 years. The subjects were divided according to age into six groups: 1-2 years, 3-4 years, 5-6 years, 7-8 years, 9-10 years, and 11-12 years. The exclusion criteria were an ocular trauma, ocular surgery, uveitis, glaucoma, cataract, corneal pathologies, vitreous pathologies, retinal pathologies, or premature retinopathy. We did not include children younger than 12 months.
Submitted for publication: November 22, 2013

Accepted for publication: March 20, 2014

Study conducted at Yuzuncu Yil University, Van, Turkey.

Ophthalmology Department, Ondokuz Mayis University, Samsun, Turkey.

2 Ophthalmology Department, Hitit University, Corum, Turkey.

Beyoglu Eye Research and Training Hospital, Istanbul, Turkey.

${ }^{4}$ Ophthalmology Department, Yuzuncu Yil University, Van, Turkey.

${ }_{5}^{5}$ Ophthalmology Department, Balikesir University, Balikesir, Turkey.
Funding: No specific financial support was available for this study.

Disclosure of potential conflicts of interest: None of the authors have any potential conflicts of interest to disclose.

Corresponding author: Adem Gul. Korfez Mah. Mehmet Akif Ersoy Bulvari, 84/15 - Atakum, Samsun - Turkey - E-mail: karsadem@yahoo.com 
We measured axial length (AL), anterior chamber depth (ACD), lens thickness (LT), vitreous chamber depth (VCD), and central corneal thickness (CCT). AL and CCT measurements were performed with the US-1800 Echoscan (Nidek, Japan) using of A-scan biometry and pachymetry probes via the contact method. The measurements were taken after instilling anesthetic drops (proparacaine) on the cornea. On average, 5 measurements were taken with the pachymetry probe and 10 measurements were taken with the biometry probe to obtain better results. All measurements were taken between 08:30 and 11:30 a.m.

In this study, 364 eyes in 182 individuals were examined. Bilateral evaluation was performed for all patients. The measurements were taken under general anesthesia for 67 patients who had an intervention (probing) for naso-lacrimal dacryostenosis. The measurements were taken during the pre-intervention period in patients who had probing. All measurements were taken by the same ophthalmologist.

Statistical analyses were completed with independently paired t-tests, ANOVAs, and correlation tests.

\section{RESULTS}

The mean age was $6.54 \pm 3.42$ years. For girls, the mean age was $6.61 \pm 3.50$ years in girls and $6.41 \pm 3.30$ years in boys. There was no significant age difference between boys and girls. Among all subjects, 63\% were boys and 37\% were girls; the ratio was 1.70 (n: boys/girls: 115/67).

The mean CCT was $556 \pm 34 \mu \mathrm{m}$. There was a significant difference between the age groups in terms of CCT. The mean AL, ACD, LT, and VCD were $22.02 \pm 1.19,3.22 \pm 0.36,3.58 \pm 0.23$, and $15.17 \pm 1.11 \mathrm{~mm}$ respectively. Details for the age groups are given in table 1 . Significant differences in the age groups were observed in the $A L, A C D, L T$, and VCD results.

Increasing age was significantly correlated with increasing $A L$, ACD, and VCD ( $p=0.000, p=0.000, p=0.000$, respectively). Although there was a significant positive correlation between $A L, A C D$, and $V C D$, there was also a significant negative association between all of the above measurements and the LT ( $p=0.054, p=0.000, p=0.000$, respectively). An important finding was that $\mathrm{LT}$ decreased as the age increased $(p=0.000)$.

When we compared girls and the boys, there were significant differences in $A L, A C D$, and VCD ( $p=0.000, p=0.001, p=0.000$, respectively), but there was no correlation in terms of CCT and LT ( $p=0.128$, $p=0.147$, respectively). The AL was $0.74 \mathrm{~mm}$ longer in boys than in girls (Graphic 1).

\section{DISCUSSION}

The most striking aspect of our study was that it was not performed with postmortem subjects or with congenital cataract patients, as could be observed in some studies ${ }^{(2,3)}$.

\section{OCular Biometry}

Most of the studies with A-scans were conducted with adolescent and adult subjects. In this study, children were studied and

Table 1. Results by age group

\begin{tabular}{lcccccc}
\hline & $\begin{array}{c}\mathbf{1 - 2} \\
\text { years }\end{array}$ & $\begin{array}{c}\mathbf{3 - 4} \\
\text { years }\end{array}$ & $\begin{array}{c}\mathbf{5 - 6} \\
\text { years }\end{array}$ & $\begin{array}{c}\mathbf{7 - 8} \\
\text { years }\end{array}$ & $\begin{array}{c}\mathbf{9 - 1 0} \\
\text { years }\end{array}$ & $\begin{array}{c}\mathbf{1 1 - 1 2} \\
\text { years }\end{array}$ \\
\hline $\mathrm{n}$ & 30 & 29 & 30 & 33 & 32 & 28 \\
$\mathrm{CCT}$ & 556 & 547 & 565 & 563 & 550 & 555 \\
$\mathrm{AL}$ & 20.49 & 21.81 & 21.97 & 22.25 & 22.66 & 22.95 \\
$\mathrm{ACD}$ & 3.06 & 3.20 & 3.02 & 3.30 & 3.31 & 3.44 \\
$\mathrm{LT}$ & 3.67 & 3.63 & 3.59 & 3.56 & 3.54 & 3.51 \\
$\mathrm{VCD}$ & 13.75 & 14.94 & 15.30 & 15.34 & 15.76 & 15.99 \\
\hline
\end{tabular}

$\mathrm{n}=$ number; $\mathrm{CCT}=$ central corneal thickness $(\mu \mathrm{m}) ; \mathrm{AL}=$ axial length $(\mathrm{mm}) ; \mathrm{ACD}=$ anterior chamber depth ( $\mathrm{mm}) ; \mathrm{LT}=$ lens thickness $(\mathrm{mm}) ; \mathrm{VCD}=$ vitreous chamber depth ( $\mathrm{mm})$. the distributions of ocular biometry and CCT were documented in a hospital-based sample of children between 1 and 12 years of age. When we reviewed the literature on ocular biometry with focusing on children, most data was from older children between 5 and 16 years of age $\mathrm{e}^{(4-7)}$

In the literature, $\mathrm{AL}$ in newborns ranged from 17 to $17.3 \mathrm{~mm}$, and rapid increase was found in the postnatal period. The $A L$ reached $20.6 \mathrm{~mm}$ after the first year of life. This rapid increase continued until the third year of life. After this rapid phase, increases in AL slowed until the seventh year and reached adult size at 10 years old ${ }^{(8-10)}$. Our study found similar results showing that AL reached $20.49 \mathrm{~mm}$ after the first year of life and reached adult levels between 9 and 10 years of age.

Gordon et al. performed a study with age groups that reported eye growth increased approximately $1 \mathrm{~mm} /$ year during the first 2 years of life, $0.4 \mathrm{~mm} /$ year between 2 and 5 years, and $0.1 \mathrm{~mm} /$ year between 5 and 15 years $^{(9)}$. In our study, similar findings showed that eye growth increased about $1 \mathrm{~mm} /$ year in the first 2 years of life and increased 0.3 to $0.4 \mathrm{~mm} /$ year after 2 years. The average annual growth rate in our study was $0.26 \mathrm{~mm}$, and we did not observe a linear increase in AL.

Our study also examined whether there were differences between girls and boys. Girls tended to have shorter eyes compared to boys. The males are typically have a deeper anterior chamber and a larger vitreous chamber. In the present study, the AL was $0.74 \mathrm{~mm}$ longer in boys than in girls. This finding is consistent with Zadnik et al., who reported that AL was longer in boys ${ }^{(10)}$. Twelker et al. and Ojaimi et al. studied AL in school-age children and reported the same findings $s^{(11,12)}$.

In our study, lens thickness was $3.67 \mathrm{~mm}$ in the first 2 years of life and $3.51 \mathrm{~mm}$ in 11-12 years (Graphic 2). Zadnik et al. studied 869 children between 6 and 14 years of age and reported that there was a decrease in lens thickness between 6 and 10 years ${ }^{(13)}$. Saw et al. studied myopic children who were between 7 and 9 years of age and reported a decrease of about $0.01 \mathrm{~mm}$ in lens thickness over 3 years ${ }^{(14)}$. The same finding was also present in Shih et al's study, which

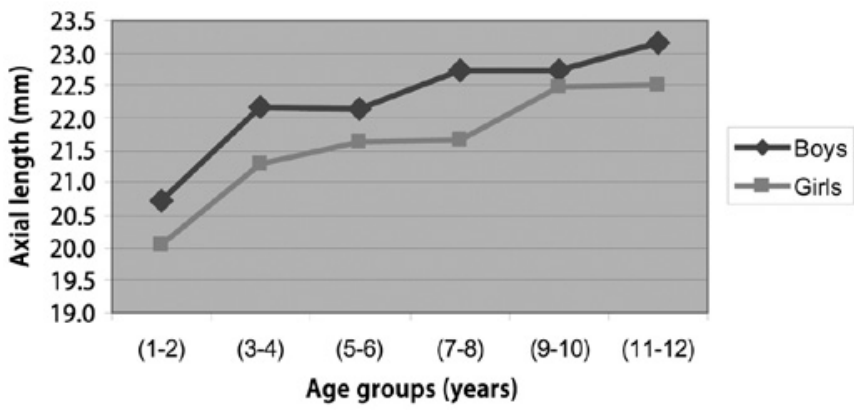

Graphic 1. Axial length in boys and girls.

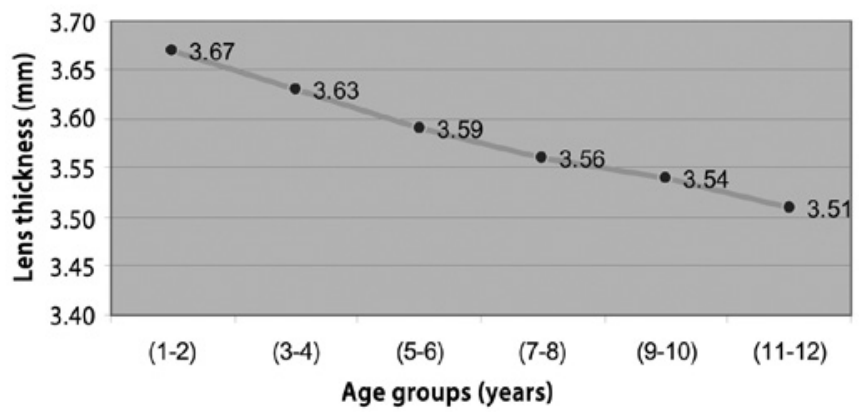

Graphic 2. Lens thickness in age groups. 
showed that a decrease was present in children between the ages of 7 and 11 years ${ }^{(15)}$. Our study found that lens thickness continuously decreased until 12 years of age. Therefore, we can say that there was a decrease in lens thickness during the first 12 years of life.

\section{Central corneal thickness}

The literature included different results about CCT in children, ranging from 529 to $564 \mu \mathrm{m}^{(16-21)}$. The average CCT in our study was $556 \mu \mathrm{m}$, and the range was between 448 and $678 \mu \mathrm{m}$.

Portellinha et al. reported that CCT is $573 \mu \mathrm{m}$ in the newborn and decreases after birth ${ }^{(22)}$. However, they did not find differences between boys and girls. In our study, there was only a 6- 4 m difference between boys and girls, which was not statistically significant.

Prost et al. studied 360 children between 0 and 14 years old ${ }^{(23)}$. In newborns, the average CCT was $537 \mu \mathrm{m}$, and at 14 years of age, the average was $567 \mu \mathrm{m}$. Parentin et al. hypothesized that this decrease took place during the first and second years of life. They claimed that rearrangements in collagen bundles and remodeling occurred in the early years of life(24).

Hussein et al. studied children between the ages of 7 months and 14 years and reported that CCT was $538 \mu \mathrm{m}$ in children under 2 years old, $546 \mu \mathrm{m}$ in children between 2 and 4 years, $565 \mu \mathrm{m}$ between 5 and 9 years, and $555 \mu \mathrm{m}$ between 10 and 14 years old. The mean CCT for all age groups was $549 \mu \mathrm{m}^{(16)}$. Our present results are similar to that study. As table 1 indicates, CCT was $556 \mu \mathrm{m}$ in the first 2 years, $547 \mu \mathrm{m}$ between 3 and 4 years, $564 \mu \mathrm{m}$ between 5 and 8 years, and $553 \mu \mathrm{m}$ between 9 and 12 years. We did not identify a gradual decrease or increase, unlike that reported in other studies ${ }^{(16,22,23)}$ in terms of CCT during the first 12 years of life. The limitations of our study for CCT are an insufficient number of subjects and the extreme measurement results in age groups that make it difficult to obtain a linear algorithm.

In conclusion, axial length was $20.49 \mathrm{~mm}$ in first 2 years. It was increasingly reached adult levels of approximately $22.66 \mathrm{~mm}$ during years 9-10. Lens thickness was $3.67 \mathrm{~mm}$ in first 2 years and continuously decreased to $3.51 \mathrm{~mm}$ up to 11-12 years old. Central corneal thickness was $556 \mu \mathrm{m}$ in the first 2 years, and $555 \mu \mathrm{m}$ in years 11-12. There was no linear increase/decrease in central corneal thickness measurements, which may be due to an insufficient subject number and extreme values in age groups.

The results of this study may contribute to the literature, particularly in the aspect of understanding pediatric eye growth and treating the most common surgical entity (congenital cataract) in early childhood period.

\section{REFERENCES}

1. Kurtz D, Manny R, OD, Hussein M. Variability of the Ocular Component Measurements in Children Using A-Scan Ultrasonography. Optom Vis Sci. 2004;81(1):35-43.

2. Augusteyn RC, Nankivil D, Mohamed A, Maceo B, Pierre F, Parel JM. Human ocular biometry. Exp Eye Res. 2012;102(3):70-5.
3. Capozzi P, Morini C, Piga S, Cuttini M, Vadalà P. Corneal curvature and axial length values in children with congenital/infantile cataract in the first 42 months of life. Invest Ophthalmol Vis Sci. 2008:49(11):4774-8.

4. Lam DS, Fan DS, Lam RF, Rao SK, Chong KS, Lau JT et al. The Effect of Parental History of Myopia on Children's Eye Size and Growth: Results of a Longitudinal Study. Invest Ophthalmol Vis Sci. 2008;49(3):873-6.

5. Tong L, Wong EH, Chan YH, Balakrishnan V. A multiple regression approach to study optical components of myopia in Singapore school children. Ophthalmic Physiol Opt. 2002:22(1):32-7.

6. Saw SM, Carkeet A, Chia KS, Stone RA, Tan DT. Component dependent risk factors for ocular parameters in Singapore Chinese children. Ophthalmology. 2002;109(11): 2065-71.

7. Jones LA, Mitchell GL, Mutti DO, et al. Comparison of ocular component growth curves among refractive error groups in children. Invest Ophthalmol Vis Sci. 2005; 46(7):2317-27.

8. Isenberg SJ. Physical and refractive characteristics of the eye at birth and during infancy. In: Isenberg SJ, editor. The eye in infancy. 2nd edition. St. Louis: Mosby; 1994; p.36-51.

9. Gordon RA, Donzis PB. Refractive development of the human eye. Arch Ophthalmol. 1985;103(6):785-9.

10. Zadnik K, Manny RE, Yu JA, et al. Collaborative Longitudinal Evaluation of Ethnicity and Refractive Error (CLEERE) Study Group. Ocular component data in schoolchildren as a function of age and gender. Optom Vis Sci. 2003;80(3):226-36.

11. Twelker JD, Mitchell GL, Messer DH, et al. CLEERE Study Group. Children's Ocular Components and Age, Gender, and Ethnicity. Optom Vis Sci. 2009;86(8):918-35.

12. Ojaimi E, Rose KA, Morgan IG, et al. Distribution of Ocular Biometric Parameters and Refraction in a Population-Based Study of Australian Children. Invest Ophthalmol Vis Sci. 2005;46(8):2748-54.

13. Zadnik K, Mutti DO, Fusaro RE, Adams AJ. Longitudinal evidence of crystalline lens thinning in children. Invest Ophthalmol Vis Sci. 1995;36(8):1581-7.

14. Saw SM, Chua WH, Gazzard G, Koh D, Tan DT, Stone RA. Eye growth changes in myopic children in Singapore. Br J Ophthalmol. 2005;89(11):1489-94.

15. Shih YF, Chiang TH, Lin LL. Lens thickness changes among schoolchildren in Taiwan. Invest Ophthalmol Vis Sci. 2009;50(6):2637-44.

16. Hussein MA, Paysse EA, Bell NP, et al. Corneal thickness in children. Am J Ophthalmol. 2004;138(5):744-8.

17. Shimmyo M, Ross AJ, Moy A, et al. Intraocular pressure, Goldmann applanation tension, corneal thickness, and corneal curvature in Caucasians, Asians, Hispanics and African Americans. Am J Ophthalmol. 2003;136(4):603-13.

18. Muir KW, Jin J, Freedman SF. Central corneal thickness and its relationship to intraocular pressure in children. Ophthalmology. 2004;111(12):2220-3.

19. Yildirim N, Sahin A, Basmak H, Bal C. Effect of central corneal thickness and radius of the corneal curvature on intraocular pressure measured with the Tono-Pen and noncontact tonometer in healthy schoolchildren. J Pediatr Ophthalmol Strabismus. 2007;44(4): 216-22.

20. Sahin A, Basmak H, Yildirim N. The influence of central corneal thickness and cornea curvature on intraocular pressure measured by tono-pen and rebound tonometer in children. J Glaucoma. 2008;17(1):57-61.

21. Coste R, Cornand E, Denis D. [Central corneal thickness in a pediatric population using a noncontact specular microscope: a study of 405 cases]. J Fr Ophtalmol. 2008; 31(3):273-8. French.

22. Portellinha W. Belfort R Jr. Central and peripheral corneal thickness in newborns. Acta Ophthalmol. 1991;69(2):247-50.

23. Prost ME, Oleszczyńska-Prost E. Central corneal thickness measurements in children. Klin Oczna. 2005;107(7-9):442-4

24. Parentin F, Pensiero S. Central corneal thickness in children with growth hormone deficiency. Acta Ophthalmol. 2010;88(6):692-4. 